\title{
环境新污染物治理与化学品环境风险防控的 系统工程
}

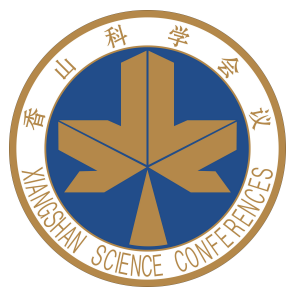

王佳钰，王中钰，陈景文，刘文佳, 崔蕴晗, 傅志强, 宋国宝

大连理工大学环境学院, 大连市化学品风险防控及污染防治技术重点实验室, 工业生态与环境工程教育部重点实验室, 大连 116024

* 联系人, E-mail: jwchen@dlut.edu.cn

2021-04-30 收稿, 2021-06-05 修回, 2021-06-05 接受, 2021-06-28 网络版发表

国家重点研发计划(2018YFC1801604, 2018YFE0110700)和国家自然科学基金(21661142001)资助

摘要重视新污染物治理, 是我国进入新发展阶段生态文明建设的必然要求. 本文介绍了新污染物的概念、来源 和特性, 指出化学品管理不当及其环境释放是新污染物的主要来源. 治理新污染物, 需要分析化学品在人类社会子 系统、新污染物在自然环境子系统中的源-流-汇; 揭示化学品和新污染物对人类社会、生态系统、无机环境系统 及各层次子系统造成的影响. 以物质流分析、生命周期评价、计算毒理学、绿色化学等现代科技手段为核心要素 的环境系统工程方法, 有助于新污染物治理和化学品风险管理. 物质流分析、生命周期评价可以追踪化学品在社 会经济系统中循环流动的源-流-汇, 进而定量其产生的潜在环境影响. 计算毒理学通过计算机模型系统性地预测释 放到环境中的化学污染物的分布和归趋，评估人类和生态物种暴露于新污染物的途径和水平，以及特定暴露条件 下, 化学污染物对人体和生态物种的有害影响. 绿色化学则要求在开发全链条中减少有害原料使用和废物排放, 并 产出低危害性或无害的化学品. 上述环境系统工程技术体系支撑化学品风险的源头防控, 进一步结合过程控制和 末端治理技术, 有望实现对新污染物的有效治理.

关键词 新污染物, 化学品, 风险防控, 环境系统工程, 源头预防

“十四五”时期，我国生态文明建设进人到生态环 境质量改善由量变到质变的关键时期. “十四五”规划 和2035年远景目标纲要指出: “重视新污染物治理”“深 人实施健康中国行动”“提升生态系统质量和稳定性”. 目前, 我国新污染物风险防范与治理体系尚不健全, 科 技支撑相对薄弱(https://www.cenews.com.cn/opinion/ 202012/t20201225_966185.html). 有必要探索新思想、 新方法, 加快推动我国新污染物治理体系的科学化、 精准化、系统化发展.

利用系统的观点分析和解决环境问题，是新时代 新发展的必然要求。“十四五”规划和2035年远景目标 纲要还指出: “坚持系统观念”“建立健全环境治理体系,
推进精准、科学、依法、系统治污，协同推进减污降 碳”. 将环境系统工程思想融人新污染物和化学品治理 中, 将有助于解决新污染物治理难题, 助力生态文明和 美丽中国建设.

\section{1 环境新污染物}

污染物是人类生产生活中有意或无意排放的，进 人环境后因超过了环境的自我消纳能力而影响环境质 量、危害人体和生态健康的物质. 根据污染物的性质, 可将其分为化学类(如化学需氧量 $(C O D)$ 、生化需氧量 $(B O D)$ 、二氧化硫 $\left(\mathrm{SO}_{2}\right)$ 、氮氧化物 $\left(\mathrm{NO}_{x}\right)$ 、细颗粒物 $\left(\mathrm{PM}_{2.5}\right)$ )、生物类(如细菌、病毒、抗性基因)和物理类 
(如光、噪声、辐射)污染物.

一些污染物较早被纳人环境监管框架中, 如 $\mathrm{COD} 、 \mathrm{BOD} 、 \mathrm{SO}_{2} 、 \mathrm{NO}_{x} 、 \mathrm{PM}_{2.5}$ 等, 可以称为常规污 染物. 常规污染物引起的环境污染问题, 多属于发达国 家数百年工业化过程中分阶段出现、分阶段解决的问 题. 因此, 常规污染物的治理, 有更多的经验遵循和技 术积累. 随着国家产业结构的调整、加大污染控制设 施投人方面举措的落实, 常规污染物导致的环境污染 问题, 会相对较快得到解决. 例如, 建设污水处理厂及 其提标改造, 有望改善水体耗氧性污染物的污染问题; 除尘和脱硫脱硝工艺, 有望减轻大气中大部分的颗粒 物、 $\mathrm{SO}_{2} 、 \mathrm{NO}_{x}$ 等污染问题.

相对于常规污染物, 新污染物可以界定为新近产 生或被新近认识的、任何人工合成或自然存在的化学 物质或微生物, 其环境赋存浓度可引起显著的已知或 可疑的毒害作用(包括对人体和生态物种的毒害、对 地球系统结构的危害, http://digitalpaper.stdaily.com/ http_www.kjrb.com/kjrb/html/2021-03/07/content_463711.htm?div=-1).

新污染物有两个主要来源: (1) 合成化学品. 即地 球上原本不存在或即使存在但含量很少、经人类有意 合成而具有某种功能和商品属性的化学物质. 一些化 学品因具有持久性、生物累积性和毒性(PBT特性), 进 人环境后对人体和生态健康造成危害, 就成为了新污 染物. 如全氟和多氟烷基化合物(PFASs) ${ }^{[1 \sim 5]}$ 、多氟醚 基磺酸类化合物 ${ }^{[6]}$ 、阻燃剂类化学品(如溴系阻燃剂、

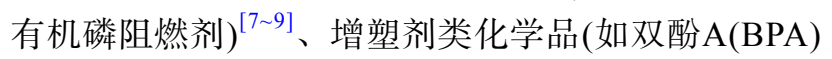

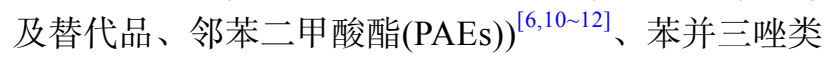
紫外线稳定剂 ${ }^{[6,10,13]}$ 、船舶防污涂料中的有机锡 ${ }^{[14]}$ 等. 化学品种类多, 大体上可分为工业化学品、农用化学 品、药物和个人护理用化学品、产品中的化学品; 美 国化学文摘社注册的化学物质已达到1.76亿种(2021年 初数据, 每天约增加8000 10000种, https://www.cas.org/), 全球市场使用的化学品及其混合物已达 35 万种 ${ }^{[15]}$.

(2) 人类活动中无意排放的有毒物质. 例如, 燃烧 和工业生产过程中产生的二啞英、化石燃料不完全燃 烧产生的多环芳烃(PAHs)、燃煤释放的录等重金属. 值得指出的是, 有些新污染物既来源于化学品, 也来源 于人类活动的副产物. 例如多氯联苯 $(\mathrm{PCBs})$, 主要来自 人工合成化学品, 但是在一些含氯有机物高温燃烧的 场景下也能产生PCBs. 环境中的PAHs主要来自化石燃 料和生物质的不完全燃烧, 但是为了科研工作和某些
特殊目的, PAHs也作为化学品标样被人工合成.

此外, 由于全球气候和生态系统的变化, 以及微生 物进化的快速迭代性, 原本在冰川、深海等区域的病 原菌和病毒可能再释放成为威胁人类健康的新污染物; 抗生素的大量使用和一些环境因子的耦合导致抗性基 因的增生和传播, 也是威胁人类健康的新污染物. 这些 生物性新污染物, 广义上也可归并到人类活动中无意 排放的有毒物质之列.

新污染物具有异于常规污染物的一些特性: (1) 污 染隐蔽性. 相对传统污染物, 新污染物环境浓度低, 其 危害性未被广泛察觉, 所以新污染物往往也是环境中 的微量或痕量污染物. (2) 环境持久性. 新污染物在环 境中往往不易降解, 呈现持久性或者由于持续地向环 境释放而呈现“假持久性”, [16]. 若不加以管理, 其环境浓 度会逐年上升，且许多新污染物容易被生物蓄积 ${ }^{[17 ~ 19]}$. (3) 释放途径多样性. 传统污染物更多是通过人类生产 生活设施进行管端排放, 便于污染控制; 而新污染物往 往在其前体及产品生命周期的多个阶段, 通过多种途 径释放到环境中. 例如, 各种产品中添加的阻燃剂、增 塑剂类化学品, 在产品的生产、运输、储存、使用和 废物处置等过程中, 可以通过排放、耗散等多种途径 进入环境中成为新污染物. (4) 危害多样性. 许多新污 染物具有内分泌干扰效应、“三致”作用等毒害效应， 其长期低剂量暴露会对生物体造成潜在危害 ${ }^{[20,21]}$. 全 球生物多样性的降低, 除了气候变化、栖息地丧失等 因素, 新污染物的污染应该有所贡献 ${ }^{[22]}$. 此外, 还有一 些新污染物危害地球系统物理结构, 最典型的是消耗 臭氧层的各种氟氯烷烃类化学物质 ${ }^{[23,24]}$. (5) 种类多样 性. 新污染物主要是化学和生物化学物质, 从物质微观 尺度的角度看, 化学物质包括以分子和高分子形态(如 微米和纳米尺度的塑料颗粒) 存在的物质、以分子聚 集体形式存在的物质(其中纳米材料是分子聚集体存 在的一种典型形式(http://paper.people.com.cn/rmrbhwb/ html/2021-02/01/content_2031981.htm), 病毒也可以视 作分子聚集体); 生物化学物质主要包括病毒在内的各 种病原微生物. 人工合成化学品是新污染物的一个重 要来源, 其本身就种类众多. (6) 治理复杂性. 传统污染 物的环境影响往往具有确定性, 而新污染物种类多、 环境中含量低、空间分布差异大, 其环境影响底数不 易摸清. 各种化学物质(尤其化学品)一旦进人环境成为 污染物, 再进行污染修复或者治理, 至少需要消耗额外 的能量而产生新的污染，完全消除其污染几乎是不可 
能实现的. 因此, 新污染物的治理, 关键在于污染预防. 如果不能有效地预防和控制新污染物的污染，其在环 境中的持续积累，会对人体和生态系统的健康产生“温 水煮青蛙”的效果. 预防新污染物的污染, 则需要评价 其环境暴露、危害性和风险性，进而降低或者阻断其 暴露, 通过研发替代性的化学品降低其危害性, 从而降 低其风险. 新污染物治理的复杂性, 凸显了环境系统工 程的思路在新污染物治理中的重要性和必要性.

\section{2 环境系统工程}

世间万物皆可视为系统, 即由部分要素组合在一 起的整体. 研究和分析系统的方法随着系统类型的不 同而存有差异. 牛顿力学和近平衡态热力学所支撑的 机械论及其对事物作分解还原式的研究, 虽能很好地 预测机械力传导和数量庞大的随机无序粒子的系统行 为, 却无法解释具有高度组织性的生命现象. 20 世纪 30 年代前后, 贝塔朗菲(Bertalanffy)创立了一般系统论, 试 图用机体论代替机械论, 强调把有机个体作为一个整 体或系统来考虑, 认为系统实行自上而下的集中控制. 但该理论主要针对受神经系统支配的个体生命，不能 推广到这些个体所组成的群体上. 20 世纪 90 年代, 圣塔 菲研究所(Santa Fe Institute)提出了复杂适应性系统理 论，认为个体之间相互作用的简单规则即可 “涌现”系 统复杂行为, 即系统由个体的相互协调自下而上地演 化 $^{[25]}$. 这些系统理论为描述客观世界系统结构与功能 (或行为)提供了基础.

分析和预测系统结构与功能并解决实际工程问题 的技术体系形成了系统工程学. 一般地, 系统工程首先 借助数学模型描述工程问题, 即工程问题模型化. 根据 观测值或实验值估计并验证数学模型参数, 进而确定 系统的目标函数, 以及变量的约束条件. 最终实现不同 条件下系统场景的模拟, 并借助优化方法确定最佳操 作条件.

20世纪60 70年代，系统工程学被应用于解决环境 问题, 产生了环境系统工程学 ${ }^{[26]}$. 早期的环境系统工程 多围绕BOD等常规污染物的治理, 以期在常规污染物 环境排放达标的前提下，尽可能降低污染治理的成本. 然而, 随着常规污染问题的解决, 新污染物与化学品不 当管理而引发的环境问题又凸显出来, 成为认识、评 价与解决环境污染损害健康问题的主要矛盾.

生态破坏与环境污染等环境问题均可视为地球表 层系统内由人类主导的对系统结构和功能的破坏. 地
球表层系统是开放、动态的复杂巨系统 ${ }^{[27,28]}$. “开放” 意味着它和宇宙环境以及地球内核交换着物质与能量. “动态”意味着它在不断地演化，包括板块构造、大气 和水体环流以及生态群落的演替等. “复杂”意味着它 的子系统种类及其间关联关系复杂，且呈现层次结构. “巨”意味着它具有数量庞大的子系统. 人类是地球表 层最活跃的因素. 因此, 地球表层系统也可看作人类社 会和自然生态系统在无机环境的基础之上相互耦合的 产物. 其中, 自然生态系统调节了地球表层的气候与无 机环境，为人类社会的可持续发展提供了空间、资源 以及非物质性的价值.

环境新污染物或化学品在地球表层系统中主要涉 及两类过程: (1) 其在人类社会子系统和自然环境子系 统中的源-流-汇关系；(2) 其对人类社会、生态系统、 无机环境系统及各层次子系统所造成的影响. 揭示其 源-流-汇关系, 可为制定新污染物治理对策提供切人 点. 评价其影响, 则可为设定系统目标函数以及约束条 件提供依据.

综上，新污染物治理和化学品环境风险防控的系 统工程是通过对两类系统过程的建模与分析，从而实 现不同治理方案下系统演化的模拟. 在保证人类社会 可持续发展的约束条件下, 最大化化学品及相关产品 带来的经济和社会效益这一目标函数, 最终选择最优 的治理策略.

环境系统工程要求坚持系统观念，注重综合治 理、系统治理、源头治理. 综合治理是从生态系统整 体性出发，运用多种治理手段对环境污染问题进行综 合分析, 调动社会各方积极参与和协同配合下, 多措并 举改善生态环境质量; 系统治理要求在治理过程中, 统 筹考虑污染物的源头预防、管端污染控制和污染场地 的修复，避免“头痛医头、脚痛医脚”的传统治理模式; 源头治理是推进生态环境质量持续改善的根本之策, 它强调在污染物进人环境前就对其加以管控，既要通 过调整产业、能源结构减少污染物排放, 又要通过分 子的绿色设计降低污染物的危害. 鉴于新污染物的特 性, 新污染物治理要在综合治理和系统治理的基础上, 牵住源头治理的“牛鼻子”, 尤其是化学品的风险防控.

\section{1 防控化学品的风险, 源头控制新污染物}

新污染物治理和化学品风险防控的系统目标是使 其环境风险、健康风险均在可控范围内，前提是需要 定量化学品的风险. 风险由化学品的暴露与危害共同 
决定 ${ }^{[29]}$. 评价暴露和危害需要明确暴露源、暴露量、 暴露途径、暴露(环境)行为、毒性(危害)类别、毒性 量效关系等信息.

物质流分析和生命周期评价有助于明确化学品的 暴露源、暴露量、暴露途径, 揭示化学品在社会经济 系统中的源-流-汇动态关系, 进而定量其产生的潜在环 境影响. 计算毒理学可通过计算机模型预测释放到环 境中的化学污染物的分布和归趋, 评估人类和生态物 种暴露于新污染物的途径和水平, 以及特定暴露条件 下, 化学污染物对人体和生态物种的不利影响. 绿色化 学要求在开发全链条中减少有害原料使用和废物排放, 并产出低危害性或无害的化学品. 这些环境系统工程 技术手段, 支持了化学品风险的源头防控, 有助于实现 源头控制新污染物(图1).

\subsection{1 量度和预测化学品的环境暴露}

鉴于环境系统空间异质且时空连续的属性, 仅采 用环境监测的手段, 难以全面系统地反映化学品和新 污染物的环境暴露, 尤其难以在化学品进人环境成为 新污染物之前, 对其可能的环境暴露进行预测. 两个基 本的环境系统工程工具, 可以用于预测化学品的暴露 源、暴露量、暴露途径, 即物质流分析(MFA)和生命 周期评价(LCA).

社会经济-环境系统是一个非线性系统, 其中存在 着复杂的物质流动关系. 为满足人类对物质的需求, 一 部分物质资源通过原材料开采等方式从环境系统流人

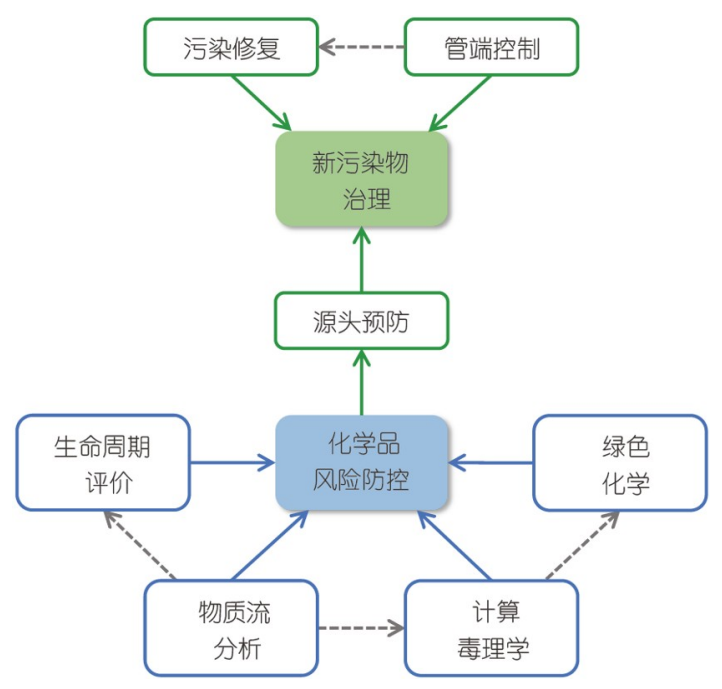

图 1 (网络版彩色)新污染物治理与化学品风险防控的系统工程框 架

Figure 1 (Color online) Framework for systems engineering of emerging pollutants treatment and chemicals risk prevention and control
社会经济系统; 进人社会经济系统的物质受人类活动 的影响, 以一定的目的在系统内部进行有序流动; 一部 分物质最终以废物的形式进人环境系统, 另一部分则 储存在了社会经济系统中. MFA即是度量社会经济-环 境系统中物质流动关系的技术手段. 它依据质量守恒 原理, 利用统计数据测算经济社会系统中物质的输人 量、储存量和输出量, 追踪物质流动的源、路径和汇, 进而为资源、废弃物和环境管理提供决策和支持.

第一个真正意义上的MFA研究始于1989年, Frosch 和Gallopoulos ${ }^{[30]}$ 评估了铂族金属在全球范围内的循环 流动情况. 2000年, 陈效述和乔立佳 ${ }^{[31]}$ 进行了MFA方面 的研究, 利用物质流的理论和方法, 分析了我国经济-环 境系统内四类物质的需求总量、消耗强度和生产力. 如今, MFA研究日益丰富并不断发展完善, 主要体现在 MFA研究范围逐步扩大, 研究的物质更加多样. 特别最 近几十年, 针对金属(如铜、铝、铁、锌、镉和关键金 属) ${ }^{[32 ~ 39]}$ 、塑料(如聚乙烯、聚丙烯、聚氯乙烯、聚苯

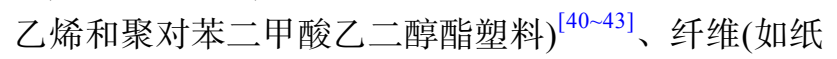
张、木材和纺织品) ${ }^{[44 \sim 66]}$ 、建筑材料(如水泥、碎石和 沙子) ${ }^{[47 ~ 49]}$ 和复合材料(如玻璃纤维、碳纤维增强聚合 物 $)^{[50,51]}$ 的MFA已在全球、国家和区域层面得到大量细 致的研究. 而在有机化学品方面, 尽管前人已对 $\mathrm{BPA}^{[52]} 、 \mathrm{PAEs}^{[53]}$ 、多溴联苯醚 $(\mathrm{PBDEs})^{[54]}$ 和PFASs ${ }^{[55]}$ 等化学品展开相关研究, 但由于有机化学品数量种类 众多, 目前的研究仍十分有限.

基于MFA量化的化学品环境释放量数据, 结合化 学品的理化性质和环境行为参数, 多介质环境模型可 进一步模拟和预测化学品在环境介质中的浓度分布和 归趋. 多介质环境模型从其本质看, 是刻画成为污染物 的化学物质在多介质环境中的源-流-汇动态关系. 1979 年, Mackay首次提出多介质逸度模型的概念 ${ }^{[56]}$, 并于 1983年构建QWASI模型模拟化学品的环境分配 ${ }^{[57]}$. 起 初, 多介质环境模型较为简单, 如空气-水 ${ }^{[58]}$ 、沉积物水 $^{[59]}$ 和空气-土壤交换模型 ${ }^{[60]}$, 这些模型通常考虑的环 境相较少, 且多虚拟环境参数, 与真实地理数据脱节. 随着计算能力的高速发展, 如今的多介质环境模型已 更加复杂和精准. 逸度模型与地理信息系统的结合还 能产生具有空间分异性的多介质环境模型. 近年来, 利 用这种空间分异性多介质环境模型的化学品环境归趋 研究日益增多. 例如, 前人已针对PBDEs ${ }^{[61]} 、 \mathrm{PAEs}^{[62]}$ 、

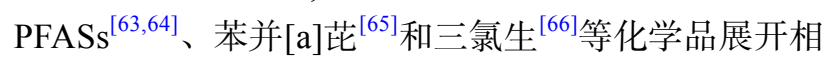
关研究. 
产品和服务是化学品的载体, 明确化学品的暴露 源、暴露量、暴露途径, 也可从这两方面人手. LCA针 对产品和服务, 从资源开采、原料生产、产品使用, 直 至废弃等全生命周期过程中的资源环境效率和潜在环 境影响进行评价, 并提出在不转移环境负担情况下的 改进方法，从而指导产品和服务改进、企业可持续性 战略以及国家可持续消费和生产政策制定等方面的决 策 ${ }^{[67 ~ 69]}$. LCA由 4 个部分组成, 即目标与范围的确定、 清单分析、影响评价和改善评价. 影响评价中, 通常将 影响类型分为资源耗竭、生态影响和人类健康三大类, 各大类又包含许多小类. 这些影响类型很多与化学品 有关. 例如, 臭氧层破坏(ODP)与氟氯烃、卤代烷、溴 甲烷等化学品息息相关, 生态毒性影响(ETP)和人体健 康损害(HTP)与进人环境介质中的化学品有着密切 联系.

1969年，美国中西部研究所对可口可乐公司不同 饮料包装瓶全生命周期的资源消耗和向环境释放的物 质所产生的环境影响进行了定量研究，揭开了LCA的 序幕 ${ }^{[70]}$. 经过不断发展, LCA现已在能源、化工、材 料、机械、建材建筑、电子电器、纺织、轻工、包 装、农业、环保、再生循环等各个领域得到应用 ${ }^{[67]}$.

\subsection{2 量度和预测生命个体对化学品的暴露}

在人类社会系统中，化学品及相关产品的生产、 流通和储存, 多以重量为度量单位, 在经济活动中呈现 出较强的组织性, 其源、流、汇可以由MFA进行统计 汇总. 化学品在释放到环境后, 多以摩尔浓度为度量单 位, 具有高度随机性, 其行为由近平衡态的热力学定律 主导. 此时, 多介质逸度模型则可以对其在无机环境介 质的分布和归趋作出较为合理的预测. 人类社会与自 然生态系统本身具有层级结构，二者的子系统均包括 生命个体. 化学品及新污染物对于人类社会与自然系 统结构的破坏方式之一，就是对其中生命个体的损害， 这表现为化学物质的毒性效应. 生命个体对化学品的 暴露则是发生毒性效应的前提.

根据有害结局路径(AOP)框架, 毒性效应起始于化 学分子与生物大分子的相互作用，进而引发后续的一 系列关键事件, 最后表现为宏观的毒理学或病理学现 象 ${ }^{[71]}$. 与外源化学分子相互作用的生物大分子在哪个 器官的什么细胞里? 这一跨越生命系统多个层次的问 题, 意味着理解化学分子在生物体内的分布规律, 有助 于理解化学品的毒性效应. 这其实是探究生物体内的 内暴露或毒代动力学行为, 是化学品污染物的源-流-汇
在生命个体这一系统中的自然延续. 生物体对化学物 质吸收、分布、代谢与排泄的毒代动力学行为, 可以 借助生理毒代动力学(PBTK)模型模拟 ${ }^{[72]}$.

借助多介质环境模型以及PBTK模型，可以大致将 遵循热力学定律的化学品浓度分布模拟出来. 然而, 暴 露因素有很多, 暴露组(exposome)表征了每个人从出生 到死亡所接触的所有暴露因素，包括物理、化学和生 物性的物质暴露以及精神性的社会压力等 ${ }^{[73]}$. 尽管化 学物质释放进人环境后, 似乎表现为从环境介质到生 物体内的“线性”过程. 但是, 考虑到人类和其他生物行 为的丰富性, 多重暴露过程交织并反馈, 呈现的却是复 杂的“非线性”过程. 围绕这种复杂暴露过程的计算模 拟形成了计算暴露科学 ${ }^{[74]}$. 在环境和生物监测大量数 据的训练和验证下，计算暴露科学可以构建起人类社 会以及自然生态系统对新污染物与化学品暴露的参数 化模型. 这些模型将有助于确定不同治理对策下人群 或生物种群对化学品暴露的状态.

\subsection{3 量度和预测化学物质的危害}

危害是化学物质引发有害效应的内禀属性. 如前 所述，新污染物问题主要来自化学品和新污染物对地 球表层系统结构和功能的破坏，其中对人类社会和生 态系统结构的破坏，包括了构成这些系统的子系统: 生命个体健康的损害. 例如, 性激素类环境内分泌干扰 物对生命个体繁殖能力的损害，会直接导致种群数目 减少, 生态系统结构变得单一和脆弱. 又如, 致癌物对 于人体健康的损害，可能会直接导致患者的精神陷人 绝望, 经济压力增加, 生活质量显著下降. 化学品对于 生命系统毒性效应的数据, 主要来自毒性测试. 然而, 以动物实验为基础的活体毒性测试法，由于动物伦理 问题而愈加受到限制. 因此，体外(in vitro)测试等动物 实验替代技术逐渐兴起. 如何将in vitro测试结果外推 至生物整体测试结果，以及如何将动物毒性测试结果 外推至人类, 均面临巨大挑战. 更重要的是, 实验测试 技术往往耗时昂贵、化学物质剂量-效应曲线复杂，而 且潜在的化学物质数目近乎天文数字, 单纯依靠实验 很难完成对所有化学品的危害评价.

为应对化学品风险评价的挑战，计算毒理学应运 而生．计算毒理学模型框架包括了前文提及的多介质 逸度模型和PBTK模型 ${ }^{[75]}$. 此外, 也包括借助理论和计 算化学原理，对引起毒性的分子起始事件(MIE)进行模 拟, 以及构建系统生物学模型, 来探究外源化学物质对 生命系统不可修复的干扰. 注意到, 不论是多介质环境 
模型还是PBTK模型，都依赖于大量的参数，如化学品 的理化性质、环境分配行为参数和生物动力学参数. 尽管监管机构和科学界已经积累了一定量上述参数的 数值, 以及毒性指标 (如 $L C_{50} 、 E C_{50}$ ) 参数, 相比于海量 的化学品数目, 这些安全性数据仍然是严重缺失的. 定 量构效关系(QSAR)模型则是填补相关数据空缺的实 用性工具 ${ }^{[29,76]}$. 借助计算毒理学的模型框架, 将实现对 化学物质毒性效应的预测与模拟，从而为定量描述新 污染物与化学品对不同物种生命个体的影响奠定基础. 最终, 个体层次的影响也将根据生态毒理学或应激生 态学的理论, 随着AOP框架放大到种群、群落乃至生 态系统层次.

降低化学品的危害性, 可以通过设计及合成替代 化学品实现. 一方面, 要考虑生产工艺的替代. 主要包 括设计环境友好、安全的新合成方法和路线、采用清 洁的化学原料、探索新的反应条件, 从而实现减少或 消除生产过程中产生的废弃物、降低能源消耗、提高 反应产率的目标. 另一方面, 也要考虑化学品功能的替 代. 主要指通过改变化学品的分子结构改变其理化性 质, 进而合成具有相似功能的低危害性化学品. 例如, 聚氨酯(PUs)通常由多元醇和聚异氭酸酯通过加聚反 应合成, 而聚异氧酸酯是基于化石资源合成的有毒化 学品. Peyrton和Avérous ${ }^{[77]}$ 设计了一种新的合成路线, 即以伯胺(或仲胺)和活化烯烃为主要原料的氮杂-迈克 尔(aza-Michael)加成反应. 该方法可从生物质资源中获 取原料, 且具有原料相对安全、反应条件温和、原子 经济性高的优势. 该研究表明通过控制反应原料、催 化剂、化学计量等因素, 新合成化学品具有与PUs相似 的功能.

绿色化学可为高性能、低风险替代化学品的研发 提供支撑. 绿色化学是在化学品的设计、制造和使用 过程中利用一系列的原则减少、甚至消除有毒有害物 质的使用或在过程中生成的方法 ${ }^{[78]}$. 绿色化学的根本 宗旨是“良性设计(benign by design)”，即从最初阶段 (即设计阶段)对分子的重要内在特性加以考虑, 以确定 生产过程和生产出的化学品是否可再生、是否具有毒 性、是否具有持久性 ${ }^{[79]}$. 利用绿色化学手段研制出的 替代品, 往往对环境更加友好, 但部分替代品由于具有 与被替代物相似的分子结构和理化性质，可能保留类 似的毒性效应. 例如, BPA由于高生殖毒性而被禁用, 用与其结构相似的双酚 S(BPS)替代BPA. 但Horan等 人 $^{[80]}$ 通过对小鼠的实验发现, BPS会影响小鼠的精子
和卵子, 也存在扰乱内分泌系统的问题. 此外, 近年来 的大量研究表明, 多数全氟辛基磺酸(PFOS)的替代物 仍保留了类似PFOS的毒性效应特征 ${ }^{[81 ~ 83]}$.

\section{2 生产过程中控制新污染物, 修复污染场地}

新污染物治理的环境系统工程以源头预防为主要 指导思想, 过程控制和末端治理也必不可少. 对于工业 生产过程中产生的新污染物, 需利用大气污染控制工 程、水污染控制工程及固体废物污染控制工程等传统 环境工程手段进行管端控制. 在管端控制过程中, 既要 消除原有污染, 又要避免引发新的污染, 尤其避免产生 二次污染，基于LCA评价不同的管端污染控制工艺技 术亦有必要. 同时, 需进行清洁生产, 追求最大化提升 资源利用效率和技术方法经济性.

对于已经进人环境中的新污染物, 需通过环境监 测手段对影响环境质量因素的代表值进行监视和测定. 基于环境监测数据, 确定主要污染源及优先控制污染 物, 进行风险评价 ${ }^{[83]}$. 进而, 对于一些特殊的污染场地, 当污染导致的风险超出某种限值而影响场地的使用功 能时, 需要对场地进行污染修复.

\section{3 防控化学品和新污染物的风险, 须强化系统性 设计}

新污染物治理的环境系统工程, 在统筹兼顾新污 染物全生命周期的基础上，还需布局新污染物治理的 长远发展. 长期来看, 要谋划好新污染物的治理, 还需 从顶层设计人手, 全面推进化学品管理体系和能力的 建设.

在化学品管理领域, “管”是多层级的. 第一层级是 要从已有化学品中篮查具有PBT特性的化学品. 第二层 级是统计化学品的生产、进口和使用量, 对体量大的 化学品开展环境浓度和暴露水平监测, 评估其环境风 险. MFA、LCA与大数据分析的结合, 可为在该层级下 摸清化学品底数提供技术保障. 确定化学品的环境浓 度和暴露水平, 评估其风险, 亦需计算毒理学的参与. 第三层级是对环境风险高的化学品加以风险管理并寻 求替代. 绿色化学则是在环境友好型替代品设计中需 要秉承的基本理念. 第四层级是将环境风险难以削减 到可接受范围的化学品纳人优先控制化学品, 对其进 行环境监管. 上述多层级管理的思路, 可为化学品管理 体系和能力的构建提供基本遵循，从而助力新污染物 治理的系统性设计. 


\section{3 展望}

以系统工程的思想进行环境新污染物治理与化学 品环境风险防控, 是我国进人新发展阶段, 生态文明建 设的必要要求. 当下, 相关研究仍处于萌芽阶段, 有很 大的进步空间.

（1）新污染物治理方法之间的交流融合有待打通. 单一方法的治理能力是有限的, 解决复杂环境问题需 要统筹兼顾，因此应注重方法间的融合．例如，基于 MFA模拟的新污染物环境暴露量, 可构建多介质环境 模型模拟新污染物在各个环境介质中的浓度，最终为 环境风险评价提供依据，由此即可实现两种方法的有 机结合.

（2）复杂环境问题的解决, 需要加强系统思想的指 导. 环境问题本身是一个复杂系统的问题. 人类在解决 单一环境问题方面已取得较为丰硕的研究成果, 如针 对一些污染物的管端排放, 实现了总量控制. 随着单一
环境问题的不断解决，新污染物问题更能体现复杂环 境问题的棘手性. 因此, 需要重视系统思想的应用, 培 养具有系统思考和解决复杂环境问题能力的高水平 人才.

(3) 新污染物治理及化学品风险防控, 亦需在“碳达 峰”和“碳中和”的目标进程中进行环境系统工程的分 析与设计. 随着全球页岩油气开采技术臻于成熟, 人类 化工行业正发生着根本性的改变. 过去, 化学品的合成 多依赖煤炭、石油中大分子原料的裂解产物. 如今, 以 小分子烷烃(天然气主要成分)、生物质、 $\mathrm{CO}_{2}$ 等为原 料的化学品合成工艺正逐渐兴起 ${ }^{[84,85]}$. 未来, 化工行业 产业链、供应链、价值链的变化，以及固碳、再利用 含碳材料工艺技术的兴迭，所带来的碳排放波动及其 对环境的影响、对化学品及新污染物治理的影响, 均 应借助环境系统工程的工具加以模拟、分析并制定 对策

\section{参考文献}

1 Ritscher A, Wang Z, Scheringer M, et al. Zürich statement on future actions on per- and polyfluoroalkyl substances (PFASs). Environ Health Perspect, 2018, 126: 84502

2 Lim X Z. Tainted water: The scientists tracing thousands of fluorinated chemicals in our environment. Nature, 2019, 566: 26-29

3 Wang Z, DeWitt J C, Higgins C P, et al. A never-ending story of per- and polyfluoroalkyl substances (PFASs)? Environ Sci Technol, 2017, 51: 2508-2518

4 Sunderland E M, Hu X C, Dassuncao C, et al. A review of the pathways of human exposure to poly- and perfluoroalkyl substances (PFASs) and present understanding of health effects. J Expo Sci Environ Epidemiol, 2019, 29: 131-147

5 Lim T C, Wang B, Huang J, et al. Emission inventory for PFOS in China: Review of past methodologies and suggestions. Sci World J, 2011, 11 1963-1980

6 Jiang G B, Ruan T, Qu G B. Theory and Analytical Methodology for Identification of Novel Environmental Organic Pollutants (in Chinese). Beijng: Science Press, 2019 [江桂斌, 阮挺, 曲广波. 发现新型有机污染物的理论与方法. 北京: 科学出版社, 2019]

7 Greeson K W, Fowler K L, Estave P M, et al. Detrimental effects of flame retardant, PBB153, exposure on sperm and future generations. Sci Rep, 2020, 10: 8567

8 Boer J, Stapleton H M. Toward fire safety without chemical risk. Science, 2019, 364: 231-232

9 Osimitz T G, Kacew S, Hayes A W. Assess flame retardants with care. Science, 2019, 365: 992-993

10 Liu X, Zeng X, Dong G, et al. Plastic additives in ambient fine particulate matter in the Pearl River Delta, China: High-throughput characterization and health implications. Environ Sci Technol, 2021, 55: 4474-4482

11 Karrer C, de Boer W, Delmaar C, et al. Linking probabilistic exposure and pharmacokinetic modeling to assess the cumulative risk from the bisphenols BPA, BPS, BPF, and BPAF for Europeans. Environ Sci Technol, 2019, 53: 9181-9191

12 Chen D, Kannan K, Tan H, et al. Bisphenol analogues other than BPA: Environmental occurrence, human exposure, and toxicity-A review. Environ Sci Technol, 2016, 50: 5438-5453

13 Baduel C, Lai F Y, van Nuijs A L N, et al. Suspect and nontargeted strategies to investigate in vitro human biotransformation products of emerging environmental contaminants: The benzotriazoles. Environ Sci Technol, 2019, 53: 10462-10469

14 Kimbrough R D. Toxicity and health effects of selected organotin compounds: A review. Environ Health Perspect, 1976, 14: 51-56

15 Wang Z, Walker G W, Muir D C G, et al. Toward a global understanding of chemical pollution: A first comprehensive analysis of national and regional chemical inventories. Environ Sci Technol, 2020, 54: 2575-2584

16 Mackay D, Hughes D M, Romano M L, et al. The role of persistence in chemical evaluations. Integr Environ Assess Manag, 2014, 10: 588-594

17 Czub G, McLachlan M S. Bioaccumulation potential of persistent organic chemicals in humans. Environ Sci Technol, 2004, 38: 2406-2412 
18 Schwarzman M R, Wilson M P. New science for chemicals policy. Science, 2009, 326: 1065-1066

19 Thomann R V. Modeling organic chemical fate in aquatic systems: Significance of bioaccumulation and relevant time-space scales. Environ Health Perspect, 1995, 103(Suppl): 53-57

20 Vandenberg L N, Colborn T, Hayes T B, et al. Hormones and endocrine-disrupting chemicals: Low-dose effects and nonmonotonic dose responses. Endocr Rev, 2012, 33: 378-455

21 Yang X H, Chen J W, Li F. Progress in computational toxicology for evaluation of thyroid disrupting effects of chemicals (in Chinese). Chin Sci Bull, 2015, 60: 1761-1770 [杨先海, 陈景文, 李斐. 化学品甲状腺干扰效应的计算毒理学研究进展. 科学通报, 2015, 60: 1761-1770]

22 Persson L M, Breitholtz M, Cousins I T, et al. Confronting unknown planetary boundary threats from chemical pollution. Environ Sci Technol, 2013, 47: 12619-12622

23 Molina M J, Rowland F S. Stratospheric sink for chlorofluoromethanes: Chlorine atom-catalysed destruction of ozone. Nature, 1974, 249: 810-812

24 Fang X, Ravishankara A R, Velders G J M, et al. Changes in emissions of ozone-depleting substances from China due to implementation of the Montreal Protocol. Environ Sci Technol, 2018, 52: 11359-11366

25 Chen Y Z. On the difference between Von Bertalanffy' general system theory and Santa Fe Institute's complex adaptive systems theory (in Chinese). J Shandong Univ Sci Technol, 2007, 2: 5-8 [陈一壮. 论贝塔朗菲的“一般系统论”与圣菲研究所的“复杂适应系统理论”的区别. 山东 科技大学学报, 2007, 2: 5-8]

26 Zhang M W. Research trends of environmental systems engineering abroad (in Chinese). Environ Sci Trends, 1981, (1): 5-7 [张孟威. 国外环境系 统工程研究动态. 环境科学动态, 1981, (1): 5-7]

27 Qian X S. Engineering technology to protect the environment—Environmental system engineering (in Chinese). Chin J Nat, 1983, (6): 1 [钱学森. 保护环境的工程技术一环境系统工程. 自然杂志, 1983, (6): 1]

28 Qian X S, Yu J Y, Dai R W. A new field of science_— Open complex giant systems and their methodology (in Chinese). Chin J Nat, 1988, 13: 310 [钱学森, 于景元, 戴汝为. 一个科学新领域——开放的复杂巨系统及其方法论. 自然杂志, 1988, 13: 3-10]

29 Chen J W, Wang Z Y, Fu Z Q. Environmental Computational Chemistry and Toxicology (in Chinese). Beijing: Science Press, 2018 [陈景文, 王中 钰, 傅志强. 环境计算化学与毒理学. 北京: 科学出版社, 2018]

30 Frosch R A, Gallopoulos N E. Strategies for manufacturing. Sci Am, 1989, 261: 144-152

31 Chen X Q, Qiao L J. Material flow analysis of Chinese economic-environmental system (in Chinese). J Nat Resour, 2000, 1: 17-23 [陈效述, 乔立 佳. 中国经济-环境系统的物质流分析. 自然资源学报, 2000, 1: 17-23]

32 Gorman M, Dzombak D. Stocks and flows of copper in the U.S.: Analysis of circularity 1970-2015 and potential for increased recovery. Resour Conserv Recycl, 2020, 153: 104542

33 Chen W, Graedel T E, Nuss P, et al. Building the material flow networks of aluminum in the 2007 U.S. economy. Environ Sci Technol, 2016, 50: 3905-3912

34 Song L, Wang P, Hao M, et al. Mapping provincial steel stocks and flows in China: 1978-2050. J Clean Prod, 2020, 262: 121393

35 Meylan G, Reck B K. The anthropogenic cycle of zinc: Status quo and perspectives. Resour Conserv Recycl, 2017, 123: 1-10

36 Shi J J, Shi Y, Feng Y L, et al. Anthropogenic cadmium cycles and emissions in mainland China 1990-2015. J Clean Prod, 2019, 230: 1256-1265

37 Tang L, Wang P, Graedel T E, et al. Refining the understanding of China's tungsten dominance with dynamic material cycle analysis. Resour Conserv Recycl, 2020, 158: 104829

38 Wang Q C, Wang P, Qiu Y, et al. Byproduct surplus: Lighting the depreciative europium in China's rare earth boom. Environ Sci Technol, 2020, 54: 14686-14693

39 Lin S, Mao J, Chen W, et al. Indium in mainland China: Insights into use, trade, and efficiency from the substance flow analysis. Resour Conserv Recycl, 2019, 149: 312-321

40 Jiang X, Wang T, Jiang M, et al. Assessment of plastic stocks and flows in China: 1978-2017. Resour Conserv Recycl, 2020, 161: 104969

41 Liu Y, Zhou C, Li F, et al. Stocks and flows of polyvinyl chloride (PVC) in China: 1980-2050. Resour Conserv Recycl, 2020, 154: 104584

42 Eriksen M K, Pivnenko K, Faraca G, et al. Dynamic material flow analysis of PET, PE, and PP flows in Europe: Evaluation of the potential for circular economy. Environ Sci Technol, 2020, 54: 16166-16175

43 Kawecki D, Scheeder P R W, Nowack B. Probabilistic material flow analysis of seven commodity plastics in Europe. Environ Sci Technol, 2018, 52: 9874-9888

44 Pivnenko K, Laner D, Astrup T F. Material cycles and chemicals: Dynamic material flow analysis of contaminants in paper recycling. Environ Sci Technol, 2016, 50: 12302-12311

45 Nørup N, Pihl K, Damgaard A, et al. Evaluation of a European textile sorting centre: Material flow analysis and life cycle inventory. Resour Conserv Recycl, 2019, 143: 310-319

46 Gonçalves M, Freire F, Garcia R. Material flow analysis of forest biomass in Portugal to support a circular bioeconomy. Resour Conserv Recycl, 2021, 169: 105507 
47 Cao Z, Shen L, Liu L, et al. Estimating the in-use cement stock in China: 1920-2013. Resour Conserv Recycl, 2017, 122: 21-31

48 Huang T, Shi F, Tanikawa H, et al. Materials demand and environmental impact of buildings construction and demolition in China based on dynamic material flow analysis. Resour Conserv Recycl, 2013, 72: 91-101

49 Tang S, Zhang L, Hao Y, et al. System dynamics modeling for construction material flows of urban residential building: A case study of Beijing, China. Resour Conserv Recycl, 2021, 168: 105298

50 Lefeuvre A, Garnier S, Jacquemin L, et al. Anticipating in-use stocks of carbon fibre reinforced polymers and related waste generated by the wind power sector until 2050. Resour Conserv Recy, 2019, 141: 30-39

51 Lefeuvre A, Garnier S, Jacquemin L, et al. Anticipating in-use stocks of carbon fiber reinforced polymers and related waste flows generated by the commercial aeronautical sector until 2050. Resour Conserv Recy, 2017, 125: 264-272

52 Jiang D, Chen W Q, Zeng X, et al. Dynamic stocks and flows analysis of bisphenol A (BPA) in China: 2000-2014. Environ Sci Technol, 2018, 52: 3706-3715

53 Muchangos L D, Xue M, Zhou L, et al. Flows, stocks, and emissions of DEHP products in Japan. Sci Total Environ, 2019, 650: 1007-1018

54 Xue M, Zhou L, Kojima N, et al. Decabromodiphenyl ether (DecaBDE) in electrical and electronic equipment in Japan: Stock, emission, and substitution evaluation. Environ Sci Technol, 2017, 51: 13224-13230

55 Chen J, Tang L, Chen W Q, et al. Flows, stock, and emissions of poly- and perfluoroalkyl substances in California Carpet in 2000-2030 under different scenarios. Environ Sci Technol, 2020, 54: 6908-6918

56 Mackay D. Finding fugacity feasible. Environ Sci Technol, 1979, 13: 1218-1223

57 Mackay D, Joy M, Paterson S. A quantitative water, air, sediment interaction (QWASI) fugacity model for describing the fate of chemicals in lakes. Chemosphere, 1983, 12: 981-997

58 Mackay D, Paterson S, Schroeder W H. Model describing the rates of transfer processes of organic chemicals between atmosphere and water. Environ Sci Technol, 1986, 20: 810-816

59 Reuber B, Mackay D, Paterson S, et al. A discussion of chemical equilibria and transport at the sediment-water interface. Environ Toxicol Chem, 1987, 6: 731-739

60 Harner T, Mackay D, Jones K C. Model of the long-term exchange of PCBs between soil and the atmosphere in the Southern U.K. Environ Sci Technol, 1995, 29: 1200-1209

61 Yan S Y, Wang Z Y, Chen J W, et al. Development of spatially differentiated multimedia environmental fugacity model to simulate fate of decabromodiphenyl ether in China (in Chinese). Asian J Ecotox, 2021, 16: 127-139 [滒世阳, 王中钜, 陈景文, 等. 反映我国空间分异特性的多介 质环境逸度模型的构建及十溴二苯梄的归趋模拟. 生态毒理学报, 2021, 16: 127-139]

62 Suzuki N, Murasawa K, Sakurai T, et al. Geo-referenced multimedia environmental fate model (G-CIEMS): Model formulation and comparison to the generic model and monitoring approaches. Environ Sci Technol, 2004, 38: 5682-5693

63 Wania F. A global mass balance analysis of the source of perfluorocarboxylic acids in the Arctic Ocean. Environ Sci Technol, 2007, 41: 4529-4535

$64 \mathrm{Su} \mathrm{C}, \mathrm{Lu}$ Y, Wang T, et al. Dynamic multimedia fate simulation of perfluorooctane sulfonate (PFOS) from 1981 to 2050 in the urbanizing Bohai rim of China. Environ Pollut, 2018, 235: 235-244

65 Zhu Y, Tao S, Price O R, et al. Environmental distributions of benzo[ $[a]$ pyrene in China: Current and future emission reduction scenarios explored using a spatially explicit multimedia fate model. Environ Sci Technol, 2015, 49: 13868-13877

66 Zhu Y, Price O R, Kilgallon J, et al. A multimedia fate model to support chemical management in China: A case study for selected trace organics. Environ Sci Technol, 2016, 50: 7001-7009

67 Hellweg S, Milà i Canals L. Emerging approaches, challenges and opportunities in life cycle assessment. Science, 2014, 344: 1109-1113

68 Azapagic A. Life cycle assessment and its application to process selection, design and optimisation. Chem Eng J, 1999, 73: 1-21

69 International Organization for Standardization. Environmental Management: Life Cycle Assessment—Principles and Framework. Geneva: International Organization for Standardization, 2006

70 Hunt R G, Franklin W E, Hunt R G. LCA-How it came about. Int J LCA, 1996, 1: 4-7

71 Ankley G T, Bennett R S, Erickson R J, et al. Adverse outcome pathways: A conceptual framework to support ecotoxicology research and risk assessment. Environ Toxicol Chem, 2010, 29: 730-741

72 Zhang S Y, Wang Z Y, Chen J W. Application of physiologically based toxicokinetics models in risk assessment of chemicals (in Chinese). Chin Sci Bull, 2017, 62: 4139-4150 [张书荣, 王中钰, 陈景文. 生理毒代动力学模型在化学品生态风险评价中的应用. 科学通报, 2017, 62: 41394150]

73 Wild C P. Complementing the genome with an "exposome": The outstanding challenge of environmental exposure measurement in molecular epidemiology. Cancer Epidemiol Biomarkers Prev, 2005, 14: 1847-1850

74 Egeghy P P, Sheldon L S, Isaacs K K, et al. Computational exposure science: An emerging discipline to support 21st-century risk assessment. Environ Health Perspect, 2016, 124: 697-702 
75 Wang Z Y, Chen J W, Qiao X L, et al. Computational toxicology: Oriented for chemicals risk assessment (in Chinese). Sci Sin Chim, 2016, 46: 222-240 [王中钰, 陈景文, 乔显亮, 等. 面向化学品风险评价的计算(预测)毒理学. 中国科学: 化学, 2016, 46: 222-240]

76 Ruan T, Jiang G B. Basic theory and analytical methodology for identification of novel environmental organic pollutants (in Chinese). Bull Chin Acad Sci, 2020, 35: 1328-1336 [阮挺, 江桂斌. 发现新型环境有机污染物的基本理论与方法. 中国科学院院刊, 2020, 35: 1328-1336]

77 Peyrton J, Avérous L. Aza-Michael reaction as a greener, safer, and more sustainable approach to biobased polyurethane thermosets. ACS Sustain Chem Eng, 2021, 9: 4872-4884

78 Anastas P T, Warner J C. Green Chemistry: Theory and Practice. Oxford: Oxford University Press, 1998

79 Zimmerman J B, Anastas P T, Erythropel H C, et al. Designing for a green chemistry future. Science, 2020, 367: 397-400

80 Horan T S, Pulcastro H, Lawson C, et al. Replacement bisphenols adversely affect mouse gametogenesis with consequences for subsequent generations. Curr Biol, 2018, 28: 2948-2954.e3

81 Nian M, Luo K, Luo F, et al. Association between prenatal exposure to PFAS and fetal sex hormones: Are the short-chain PFAS safer? Environ Sci Technol, 2020, 54: 8291-8299

82 Zhang H, Zhou X, Sheng N, et al. Subchronic hepatotoxicity effects of 6:2 chlorinated polyfluorinated ether sulfonate (6:2 Cl-PFESA), a novel perfluorooctanesulfonate (PFOS) alternative, on adult male mice. Environ Sci Technol, 2018, 52: 12809-12818

83 Jiang G B, Song M Y. Environmental Exposure and Health Effects (in Chinese). Beijing: Science Press, 2020 [江桂斌, 宋茂勇. 环境暴露与健康 效应. 北京: 科学出版社, 2020]

84 Allen D T, Tran C, Zeitler E. National academies report defines a research agenda for chemical, biochemical and mineralization approaches to gaseous carbon waste utilization. ACS Sustain Chem Eng, 2019, 7: 3702-3709

85 Rossi L M, Gallo J M R, Mattoso L H C, et al. Ethanol from sugarcane and the Brazilian biomass-based energy and chemicals sector. ACS Sustain Chem Eng, 2021, 9: 4293-4295 


\title{
Environmental systems engineering consideration on treatment of emerging pollutants and risk prevention and control of chemicals
}

\author{
Jiayu Wang, Zhongyu Wang, Jingwen Chen", Wenjia Liu, Yunhan Cui, Zhiqiang Fu \& Guobao Song \\ Key Laboratory of Industrial Ecology and Environmental Engineering (Ministry of Education), Dalian Key Laboratory on Chemicals Risk Control and \\ Pollution Prevention Technology, School of Environmental Science and Technology, Dalian University of Technology, Dalian 116024, China \\ * Corresponding author, E-mail: jwchen@dlut.edu.cn
}

As the impact of emerging pollutants (EPs) on human health and ecosystems becomes significant, attention is being drawn to the treatment of EPs. Unlike conventional pollutants (e.g., chemical oxygen demand, biochemical oxygen demand, $\mathrm{SO}_{2}$, $\mathrm{NO}_{x}$, etc.), EPs have relatively short history of use and production, or have their hazards be identified only recently, and thus are largely beyond the scope of current laws or regulations on environmental pollutants. Synthetic chemicals and unintentionally released chemical substances constitute an important source of EPs. EPs have diverse chemical structures and can take varied forms, including molecules, polymers, and aggregates. EPs can be released into the environment via multiple routes during the life cycle of products that contain corresponding chemicals. In the environment, EPs can be persistent or pseudo-persistent due to continuous release and resistance to degradation. EPs can exert a variety of hazardous effects, including endocrine disruption, carcinogenicity, mutagenicity, etc. In addition, the chronical effects tend to be insidious. All these features have complicated the treatment and control of EPs, resulting in high cost for restoring the contaminated environment. Hence, it is recognized that the key to the treatment of EPs is to prevent potential pollution of the corresponding chemicals.

In order to address the issues of EPs, environmental systems engineering (ESE) thinking is required. Environmental issues such as ecological damage and environmental pollution can be regarded as human activity-induced devastation to the structure and function of the Earth surface system, which involves two EPs or chemicals-related processes: (1) The sources, flows and sinks of EPs or chemicals in the human society and natural environmental system, which are informative for controlling policies and strategies to intervene; (2) the effects of EPs or chemicals on the human social system, ecosystem and inorganic environmental system, which provide the basis for setting "objective functions and constraint conditions" for sustainable development of the system. Briefly, ESE for the treatment of EPs and the risk management of chemicals, aims to realize the simulation of systems evolution under various treatment scenarios, by modeling and analyzing the above EPs and chemicals-involved processes in the human society and the natural environmental system. With the constraints on the sustainability of human society, the objective functions, i.e., the economic and social benefits of chemicals and related products, are maximized. Then, the best strategies and practice for the treatment of EPs could be reasonably selected.

Several ESE technologies are discussed, among which material flow analysis and life cycle assessment could track the sources, flows, and sinks of chemicals in the human society-economy system, and further quantify their impacts on the environment. Computational toxicology could, via in silico simulations, predict the distribution and fate of EPs, estimate the exposure of human and ecological species to the EPs, and evaluate the adverse effects of EPs on human and ecological species under certain exposure levels. Green chemistry, namely "benign by design", on the other hand, aims to diminish the use of hazardous feedstocks and the release of waste, and eventually design and produce chemicals with low or zero hazards. All these ESE technologies combined with the relatively conventional process control and terminal treatment technologies, are promising for supporting the risk prevention and control of chemicals, as well as the effective treatment of EPs.

emerging pollutants, chemicals, risk prevention and control, environmental systems engineering, source prevention

doi: 10.1360/TB-2021-0422 